\title{
Features of the inheritance of fruit size in the hybrid families of prunus domestica
}

\author{
G. E. Osipov* and Z. A. Osipova
}

Department of agricultural biotechnology, Tatar Scientific Research Institute of Agriculture, FRC Kazan Scientific Center, Russian Academy of Sciences, 420059 Kazan, Republic of Tatarstan, Russia

\begin{abstract}
The aim of the research was to establish the features of the inheritance of the size of the fruit in the hybrid families of Prunus domestica. The objects of study were hybrid seedlings of plum selection of the Tatar research Institute of agriculture. Fruit sizes were estimated according to the methodology of the all-Russian research Institute of fruit crops selection. The analysis of the splitting of plum in hybrid families by the size of fruits showed that seedlings with small fruits dominated in the breeding gardens of the Tatar research Institute. The size of the plum fruit is controlled by polygens. All of the original parental forms are heterozygotes for the genes determining the size of the fruit. A small fruit is a dominant trait, a large fruit is a recessive trait. In most hybrid families, plum seedlings have a significant variability in the size of the fruit. Transgressive genotypes with large fruits are formed in hybrid families Eurasia 21 x Renklod Tenkovsky, Eurasia $21 \mathrm{x}$ free pollination and Zyuzinskaya $\mathrm{x}$ free pollination. The varieties Eurasia 21 and Zyuzinskaya must be used as sources in breeding of plums for large-fruited.
\end{abstract}

\section{Introduction}

Plum is one of the leading fruit crops in the world. According to the gross harvest of fruits among stone crops, it ranks second after peach. Plum fruits are valued for good taste, the content of nutrients and biologically active substances that have a beneficial effect on human health. Plum fruits are suitable for fresh consumption, drying, canning, freezing, making jam and jelly [1-3].

In Europe, plums are the main types of fruit crops, occupying an area of about 500,000 hectares and producing about 3 million tons of fruit. The main plum growing countries: Serbia [4], Romania [5], Italy [6], Germany [7], Bulgaria [8], and other countries have seen a decline in their production, mainly due to viral diseases that have damaged orchards and degraded the quality of the fruit. Therefore, in these countries, large breeding programs have been developed for the development of new fruit that are productive, resistant to diseases, pests, climate change, poor soil varieties with good quality and keeping [7-14].

The creation of varieties by controlled crosspollination is a common method of obtaining new varieties of plum in many countries of Europe and the world [9]. The desired size of the fruit Prunus domestica in Central Europe and most Eastern European countries is $30-40 \mathrm{~g}$. The fruits of most recently bred varieties of plum are of the same size [7]. Due to the high degree of heterozygosity of plum and its home hexaploid nature, it is difficult to investigate the inheritance of signs $[9,15-$
17]. The plum fruit size is inherited as a quantitative trait $[7,15,18-23]$.

The sign "fruit size" is controlled polygenically. In some families, a small percentage of seedlings with fruits is larger than that of the larger parent (positive transgression). To produce large-fruited offsprings, usually large-fruited varieties are involved in hybridization [21, 24]. If both parents have large fruits, then the offspring will basically have smaller fruits than their parents do. Only $2.8 \%$ of all hybrids bear fruits larger than those of their parents [7]. Kozlovskaya Z. A. (1985) and V. Matveev (1987) noted the dominance of small fruit plums.

Most hybrids are close to their original forms in terms of the fruits size, but also there is often negative transgression [24]. The newest sources of large fruits obtained in the VNIIGiSPR G.A. Kursakov are the Starting variety with a mass of fruit reaching $80 \mathrm{~g}$ [25].

V.A. Matveyev (1987), studying the size of fruits in hybrid seedlings of domestic plums, found that the coefficient of heritability of this trait in a broad sense $(\mathrm{H} 2)$ is 0.11 . In plums, the coefficient of heritability of the fruits size in the narrow sense is $0.50-0.52$ [22, 23]. This means that the correct selection of parents by phenotypic values of hybridization will lead to significant progress in the breeding of plums to increase the size of the fruit.

The size of the fruits of the Chinese plum varieties is controlled by polygens, which determines the variability in offspring. All genotypes of plum hybrids are very heterogeneous. The size of the fruit tends to be a recessive trait. For breeding purposes, it is recommended

\footnotetext{
* Corresponding author: osipovge@ mail.ru
} 
to use varieties with good cold resistance and large fruits resebling parent plants [26].

\section{Materials and methods}

Breeding plum orchards of Tatar research Institute are located in the South-Western part of the Republic of Tatarstan, on the right Bank of the Volga river. Gardens are not irrigated. Farming - common to stone fruit crops in Tatarstan. The analysis of splittings by the size of fruits in hybrid families of plums was carried out in the Tenkovsky Department of Horticulture of Tatar Research Institute of Agriculture in 1993, 1998 and 2000-2004. During these years, favorable weather conditions were established in terms of air temperature and humidity for the formation of good quality plum fruits.

The objects of study of the fruit size were hybrid plum seedlings in breeding gardens of 1986, 1987 planting: Eurasia 21 x Renklod Tenkovsky (36 pcs.), Tatar Yellow x Vengerka Tenkovskaya (18 pcs.), Skorospelka Red x Vengerka Tenikovskaya (15 pcs.), Renclod Tenkovsky x Renklod Tenkovsky (63 pcs.); 1995, 1997 planting: Eurasia 21 x free pollination (68 pcs.), Zyuzinskaya $\mathrm{x}$ free pollination (49 pcs.), Tatar Yellow x free pollination (22 pcs.), Tenkovskaya Dove $\mathrm{x}$ Renklod Tenkovsky (17 pcs.); 1996 planting: Renklod Tenkovsky x Renklod Tenkovsky (87 pcs.), Skorospelka Red $x$ free pollination (67 pcs.), Tenkovskaya Dove $\mathrm{x}$ Skorospelka Red (37 pcs.), Tenkovskaya Dove x Egg (35 pcs.), Eurasia $21 \mathrm{x}$ free pollination (34 pcs.), Tenkovskaya Dove x Renklod Tenkovsky (17 pcs.), Daughter of Tatarstan x Tatar Dessert (15 pcs.).

The size of the fruits was assessed according to the methodology of the All-Russian Research Institute for
Breeding Fruit Crops [27], transgressions were determined in accordance with the methodology [28], the variation coefficients - according to the method of B.A. Dospehov [29].

\section{Results and discussion}

In the breeding garden of plums No. 8 in all hybrid families, seedlings with small fruits (table 1) dominated (44.4-95.3\%). In the progeny from crossing small-fruited varieties of Skorospelka Red x Vengerka Tenkovskaya, Renklod Tenkovsky x Renklod Tenkovsky and Tatar Yellow x Vengerka Tenkovskaya most of the hybrids $(61.1-95.3 \%)$ had small fruits.

Transgressive seedlings with medium fruits were isolated in the families of small-fruited parents Tatar Yellow x Vengerka Tenkovskaya (38.9\%), Skorospelka Red x Vengerka Tenkovskaya (6.7\%) and Renklod Tenkovsky x Renklod Tenkovsky (4.7\%) (table 1). From hybridization of middle-fruited variety Eurasia 21 with small-fruited variety, Renklod Tenkovskiy hybrids were obtained, most of which $(44.4 \%)$ had small fruits. In this family, there is a significant percentage $(38.9 \%)$ of medium-fruited and small percentage $(16.7 \%)$ of largefruited (transgressive) seedlings (table 1).

In a hybrid family Eurasia 21 x Renklod Tenkovskiy, the degree of positive transgression of the size of fruits was $42.8 \%$, the degree of negative transgression $10.6 \%$. The frequency of positive transgressions was $27.8 \%$, the frequency of negative transgressions was $26.7 \%$. In this hybrid family, there is a significant variability in the size of the fruit $(\mathrm{CV}=25.9 \%)$. A significant variability in the size of the fruit increases the probability of selection of hybrids with large fruits.

Table 1. Splitting the size of the fruit in hybrid families of plums. Garden No. 8. 1993, 1998

\begin{tabular}{|c|c|c|c|c|c|c|}
\hline Cross combination & Number of & \multicolumn{5}{|c|}{ The percentage of seedlings with fruits } \\
\cline { 3 - 7 } & seedlings & $\begin{array}{c}\text { highly } \\
\text { small, } \\
\text { up to } 10 \mathrm{~g}\end{array}$ & $\begin{array}{c}\text { small, } \\
10-20 \mathrm{~g}\end{array}$ & $\begin{array}{c}\text { medium, } \\
21-30 \mathrm{~g}\end{array}$ & $\begin{array}{c}\text { large, 31- } \\
40 \mathrm{~g}\end{array}$ & $\begin{array}{c}\text { highly } \\
\text { large, } \\
\text { more than }\end{array}$ \\
\hline $\begin{array}{c}\text { Renklod Tenkovsky } \mathrm{g} \\
\text { Renklod Tenkovsky }\end{array}$ & 63 & 0 & 95.3 & 4.7 & 0 & 0 \\
\hline $\begin{array}{c}\text { Eurasia 21 x Renklod } \\
\text { Tenkovsky }\end{array}$ & 36 & 0 & 44.4 & 38.9 & 16.7 & 0 \\
\hline $\begin{array}{c}\text { Tatar Yellow x } \\
\text { Vengerka Tenkovskaya }\end{array}$ & 18 & 0 & 61.1 & 38.9 & 0 & 0 \\
\hline $\begin{array}{c}\text { Skorospelka Red x } \\
\text { Vengerka Tenkovskaya }\end{array}$ & 15 & 0 & 93.3 & 6.7 & 0 & 0 \\
\hline
\end{tabular}

In the hybrid family Renklod Tenkovskiy x Renklod Tenkovskiy the degree of positive transgression in the size of the fruit was $31.1 \%$, the degree of negative transgression - 34.4\%. The frequency of positive transgressions was $4.7 \%$, the frequency of negative transgressions $-77.8 \%$. The variability of the fruit size was average and amounted to $15.1 \%$.

In a hybrid family Tatar Yellow $x$ Vengerka Tenkovskaya the degree of positive transgression in the size of the fruit was $20.8 \%$, the degree of negative transgression - $1.4 \%$. The frequency of positive transgressions was $38.9 \%$, the frequency of negative transgressions $-5.6 \%$. In the hybrid offspring there is an average variability in the size of the fruit $(\mathrm{CV}=16.0 \%)$.

In the hybrid family Skorospelka Red x Vengerka Tenkovskya the degree of positive transgression in the size of the fruit was $16.7 \%$, the degree of negative transgressions - 7.9\%. The frequency of positive 
transgressions was $6.7 \%$, the frequency of negative transgressions $-20 \%$. In the hybrid family there is an average variability of the fruit size $(15.4 \%)$.

Consequently, the evaluation of plum hybrid families showed that in breeding garden № 8 is dominated by small-fruited seedlings. In a small number of largefruited seedlings were isolated. In all families there are hybrids with both positive transgression in the size of the fruit and negative transgression. For breeding, the source of large-fruited is the plum Eurasia 21. The variability of the size of the fruit was significant in only one family Eurasia 21 x Renklod Tenkovsky.

In this family, promising hybrid seedlings were later selected by the size of the fruit and other traits (8-3-84, $8-4-52,8-4-76)$. The peculiarities of splitting by the size of the fruit and the variability of this trait in seedlings in hybrid families indicate the heterozygosity of the original parental varieties and the polygenic character of inheritance of the trait.

In breeding garden No. 1, as well as in garden No. 8, small-fruited plum seedlings dominated (42.9-88.2\%) (table 2). Seedlings with medium-sized fruits were isolated in two hybrid families, obtained from crossing small-fruited varieties between themselves and two families from free pollination of medium-fruited varieties.

The largest percentage of seedlings with fruits of average size was isolated in families from free pollination of medium-fruited varieties Zyuzinskaya (32.6\%) and Eurasia 21 (25.0\%). Hybrids with large fruits (transgressive) were found in families where the mother forms were middle-fruited varieties Zyuzinskaya $(24.5 \%)$ and Eurasia 21 (11.8\%).

Table 2. Splitting the size of the fruit in hybrid families of plums. Garden No. 1. 2000-2004

\begin{tabular}{|c|c|c|c|c|c|c|}
\hline \multirow[b]{2}{*}{ Cross combination } & \multirow{2}{*}{$\begin{array}{l}\text { Number of } \\
\text { seedlings }\end{array}$} & \multicolumn{5}{|c|}{ The percentage of seedlings with fruits } \\
\hline & & $\begin{array}{l}\text { Highly } \\
\text { small, up } \\
\text { to } 10 \mathrm{~g} \\
\end{array}$ & $\begin{array}{l}\text { small, } \\
10-20 \mathrm{~g}\end{array}$ & $\begin{array}{l}\text { medium, } \\
21-30 \mathrm{~g}\end{array}$ & $\begin{array}{c}\text { large, } 31-40 \\
g\end{array}$ & $\begin{array}{l}\text { Highly large, } \\
\text { more than } 40 \\
\mathrm{~g}\end{array}$ \\
\hline $\begin{array}{c}\text { Eurasia } 21 \mathrm{x} \\
\text { free pollination }\end{array}$ & 68 & 0 & 63.2 & 25 & 11.8 & 0 \\
\hline Zyuzinskaya $\mathrm{x}$ free pollination & 49 & 0 & 42.9 & 32.6 & 24.5 & 0 \\
\hline Tatar Yellow $\mathrm{x}$ free pollination & 22 & 0 & 86.4 & 13.6 & 0 & 0 \\
\hline $\begin{array}{l}\text { Tenkovskaya Dove } \mathrm{x} \\
\text { Renklod Tenkovsky }\end{array}$ & 17 & 0 & 88.2 & 11.8 & 0 & 0 \\
\hline
\end{tabular}

Seedlings with positive transgression are most often found in hybrid families Tatar Yellow $\mathrm{x}$ free pollination $(45.5 \%)$ and Zyuzinskaya $x$ free pollination $(36.7 \%)$. According to the variability of the size of the fruit, the hybrid families Zyuzinskaya x free pollination (31.9\%) and Eurasia $21 \mathrm{x}$ free pollination $(31.7 \%)$ stood out. Later, in these families promising hybrids were selected: 1-2-36, 1-2-60, 1-1-75 and 1-1-84.

Consequently, the analysis of hybrid families showed that small-fruited hybrid seedlings dominate in breeding garden No. 1 as in garden No. 8. Hybrids with large fruits are obtained in families from the free pollination of varieties with medium-sized fruits of Zyuzinskaya and Eurasia 21. For selection, the sources of large fruits are the plums of Zyuzinskaya and Eurasia 21.

Some seedlings have a positive and negative transgression in terms of the size of the fruit. The nature of the splitting in size of the fruit and the variability of this trait in seedlings in hybrid families make it possible to assume that the original parental varieties are heterozygotes and the trait is controlled by polygenes.

In selection garden number 3 , most of the hybrid seedlings also had small fruits (table 3 ). This is due to the fact that these hybrid families were obtained from crossing small-fruited varieties, except for the families of Eurasia $21 \mathrm{x}$ free pollination and Daughter of Tatarstan x Tatar Dessert, where the parent varieties had fruits of medium size.

In families of small-fruited parents Tenkovskaya Dove $x$ Egg and Tenkovskaya Dove $x$ Renklod
Tenkovsky we marked only small-fruited hybrids (table $3)$.

The largest percentage of seedlings with mediumsized fruits was established in families: Daughter of Tatarstan x Tatar Dessert (33.3\%) and Skorospelka Red $\mathrm{x}$ free pollination $(23.9 \%)$. Somewhat less middle-fruited hybrids were obtained from the hybridization of smallfruited varieties Renklod Tenikovsky $x$ Renklod Tenikovsky (12.9\%) and Tenkovskaya Dove x Skorospelka Red (5.4\%).

The appearance in these families of seedlings with larger fruits than those in the parental forms is apparently associated with positive transgression. Medium-fruit hybrids were isolated in the family Eurasia $21 \mathrm{x}$ free pollination $(20.6 \%$ ) (table 3 ). In this same family a few seedlings had large fruits (more than $31 \mathrm{~g}$ ). There may be also positive transgression.

In the hybrid families the Tenkovskaya Dove $\mathrm{x}$ Renklod Tenkovsky, Tenkovskaya Dove x Egg and Tenkovskaya Dove x Skorospelka Red seedlings with small fruits were $94.6-100 \%$. It can be assumed that the variety Tenkovskaya Dove has in its genotype mainly dominant alleles of the genes controlling the small size of the plum fruit. Variety Tenkovskaya Dove is a source of small plums.

A significant degree of positive transgression was found in seedlings in hybrid families of the Tenkovskaya Dove x Skorospelka Red (56.4\%), Renklod Tenkovsky x Renklod Tenkovsky (38.9\%) and Eurasia $21 \mathrm{x}$ free pollination $(34.8 \%)$. High frequency in the seedlings with a positive transgression in the progeny Tankovska 
Dove x Skorospelka Red was observed (43.2\%). In the three hybrid families listed above, a significant variability of the fruit size (20.2-23.3\%) was established. The maximum frequency of seedlings with a negative transgression was established in the hybrid families
Renklod Tenkovsky x Renklod Tenkovsky (73.6\%), as in Garden No. 8 (77.8\%). This happened possibly due to an increase in the hybrid seedlings of the dominant alleles of the genes that control the small size of the plum fruits.

Table 3. Splitting the size of the fruit in hybrid families of plums. Garden No. 3. 2000-2004

\begin{tabular}{|c|c|c|c|c|c|c|}
\hline \multirow[b]{2}{*}{ Cross combination } & \multirow{2}{*}{$\begin{array}{l}\text { Number } \\
\text { seedlings }\end{array}$} & \multicolumn{5}{|c|}{ The percentage of seedlings with fruits } \\
\hline & & $\begin{array}{l}\text { highly } \\
\text { small, } \\
\text { up to } \\
10 \mathrm{~g}\end{array}$ & $\begin{array}{l}\text { small, } \\
10-20 \mathrm{~g}\end{array}$ & $\begin{array}{l}\text { medium, } \\
21-30 \mathrm{~g}\end{array}$ & $\begin{array}{l}\text { large, } 31- \\
\quad 40 \mathrm{~g}\end{array}$ & $\begin{array}{l}\text { highly } \\
\text { large, } \\
\text { more than } 40\end{array}$ \\
\hline $\begin{array}{l}\text { Renklod Tenkovsky x } \\
\text { Renklod Tenkovsky }\end{array}$ & 87 & 0 & 87.1 & 12.9 & 0 & 0 \\
\hline $\begin{array}{c}\begin{array}{c}\text { Skorospelka Red } \mathrm{x} \\
\text { free pollination }\end{array} \\
\end{array}$ & 67 & 0 & 76.1 & 23.9 & 0 & 0 \\
\hline $\begin{array}{c}\text { Tenkovskaya Dove x Skorospelka } \\
\text { Red }\end{array}$ & 37 & 0 & 94.6 & 5.4 & 0 & 0 \\
\hline Tenkovskaya Dove x Egg & 35 & 0 & 100 & 0 & 0 & 0 \\
\hline Eurasia $21 \mathrm{x}$ free pollination & 34 & 0 & 76.5 & 20.6 & 2.9 & 0 \\
\hline $\begin{array}{l}\text { Tenkovskaya Dove x } \\
\text { Renklod Tenkovsky } \\
\end{array}$ & 17 & 0 & 100 & 0 & 0 & 0 \\
\hline $\begin{array}{l}\text { Tenkovskaya Dove x } \\
\text { Renklod Tenkovsky }\end{array}$ & 15 & 0 & 66.7 & 33.3 & 0 & 0 \\
\hline
\end{tabular}

Consequently, the analysis of hybrid families of plum showed that breeding garden No. 3 is dominated by seedlings from small fruits. Hybrids with large fruits are obtained from free pollination of plum Eurasia 21. Some hybrid seedlings showed positive transgression in size of the fruit, other seedlings - negative transgression. Given the nature of the cleavage in the size of the fruit and the variability of this trait in plum seedlings in hybrid families, it can be assumed that the original parent varieties are heterozygotes and the trait is controlled by polygenes.

\section{Conclusion}

Given there are small amounts of offspring in hybrid families Prunus domestica, we can draw preliminary conclusions on the peculiarities of inheritance of the size of the fruit. An analysis of the splitting in hybrid families of plum by the size of fruits showed that seedlings with small fruits dominate in the breeding gardens of Tatar research Institute.

The size of the plum fruit is controlled by polygens. All of the original parental forms are heterozygotes for the genes determining the size of the fruit. Small fruits are controlled by dominant alleles of genes, large fruits by recessive alleles of genes. Self-pollination of the Renklod Tenkovsky variety increases the number of dominant alleles of genes that control the small size of fruits.

Transgressive genotypes with large fruits are formed in hybrid families Eurasia 21 x Renklod Tenkovsky, Eurasia $21 \mathrm{x}$ free pollination and Zyuzinskaya $\mathrm{x}$ free pollination. The varieties Eurasia 21 and Zyuzinskaya must be used as sources in the selection of plums for large fruits.

\section{References}

1. M. Gunes, Some Local Plum Varieties Grown in Tokat Province, J. of Applied Sciences, 3, 291-295 (2003) DOI: 10.3923 / jas.2003.291.295

2. V.L. Vitkovsky, Fruit plants of the world (St. Petersburg; Moscow; Lan, Krasnodar, 2003)

3. T.C. Wallace, Dried Plums, Prunes and Bone Health: A Comprehensive Review, Nutrients, 9(4), 401 (April 2017) DOI: 10.3390/nu9040401

4. S. Petrović, A. Leposavić, D. Ogasanović, B. Popović, Profitability of plum production and processing under the conditions of western Serbia, in ISHS Acta Horticulturae 734: VIII Int. Symp. on Plum and Prune Genetics, Breeding and Pomology (2007) DOI: 10.17660/ActaHortic.2007.734.61

5. I. Botu, M. Botu, G. Achim, A. Baciu, Plum culture in Romania: present situation and perspectives, Acta Horticulturae, 874, 365-372 (2010) DOI: 10, 17660 / ActaHortic.2010.874.52

6. F. Sottile, E. Bellini, V. Nencetti, P. Cristiana, Plum production in Italy: State of the art and perspectives, Acta Horticulturae, 874(874), 25-34 (September 2010) DOI: 10.17660/ActaHortic.2010.874.2

7. W. Hartmann, M. Neumuller, Plum Breeding, in the book Breeding Plantation Tree Crops: Temperate Species, 161-231 (2009) DOI: 10.1007/978-0-38771203-1_6

8. I. Vitanova, S. Dimkova, N. Marinova, D. Ivanova, H. Kutinkova, Pomological and chemical characteristics of some Bulgarian plum cultivars, 
Acta Hortic., 874, 317-320 (2010) DOI: 10.17660/ActaHortic.2010.874.45

9. H.B. Jacob, Ripening time, quality and resistance donors of genotypes of Prunus domestica and their inheritance pattern in practical plum breeding, Acta Horticulturae, 734, 77-82 (2007) DOI: 10.17660/ActaHortic.2007.734.7

10. A. Zhivondov, V. Bozhkova, New Bulgarian plum cultivars, Acta Horticulturae, 874, 345-350 (2010) DOI: $10.17660 /$ ActaHortic.2010.874.49

11. M. Botu, G. Achim, I. Botu, S. Preda, A. Baciu, New cultivars and elites for plum culture in Romania, Acta Horticulturae, 874, 293-298 (2010) DOI: 10.17660/ActaHortic.2010.874.41

12. M. Butac, V. Bozhkova, A. Zhivondov, N. Milošević et al., Overview of plum breeding in Europe, Acta horticulturae, 981(981), 91-98 (2013) DOI: 10.17660 / ActaHortic.2013.981.9.19

13. M. Butac, M. Botu, M. Madalina, D.I. Sumedrea, Old autochthonous Romanian plum genotypes - a source for breeding program, Acta horticulturae (2017) DOI: 10.17660/ActaHortic.2017.1175.7

14. T. Milošević, N. Milošević, Plum (Prunus spp.) Breeding: Volume 3, in book: Advances in Plant Breeding Strategies: Fruits, part of Springer Nature, 165-215 (International Publishing AG, 2018) DOI: 10.1007/978-3-319-91944-7_5

15. G.V. Eremin, A.V. Isachkin, I.V. Kazakov et al., General and private breeding and cultivation of fruit and berry crops (Moscow, Mir, 2004)

16. G.E. Osipov, Z.A. Osipova, The nature of the inheritance of the taste of fruits in the hybrid families of the Prunus domestica, Horticulture and viticulture, 2, 39-42 (2011)

17. G.E. Osipov, Z.A. Osipova, Inheritance of productivity in the hybrid families of the Prunus domestica, Horticulture and Viticulture, 3, 22-27 (2018) DOI: 10.25556/VSTISP.2018.3.14301

18. Z.A. Kozlovskaya, Inheritance of economic, biological and morphological traits in the hybrid progeny of home plum, candidate dissertation thesis (Samokhvalovichi, Minsk region, 1985)

19. V.A. Matveev, Culture of plums and the breeding of new varieties in Belarus, candidate dissertation thesis (Zhodino, 1987)

20. W. Hartmann, Hohenheimer Pflaumen - und Zwetschenzuchtung, Erwerbs - Obstbau, 41(3-4), 75-80 (1999)

21. R. Sh. Zaremuk, Inheritance of some signs of plum hybrid offspring, Agrarian science, 11, 13-14 (2001)

22. S.H. Hjeltnes, L. Nornes, O.A. Rognli, Inheritance of some fruit characters in plum (Prunus domestica L.), Acta horticulturae, 874(874), 45-50 (2010) DOI: 10.17660/ActaHortic.2010.874.4

23. B. Carrasco, L. Meisel, M. Gebauer, R. GarciaGonzales, H. Silva, Breeding in peach, cherry and plum: from a tissue culture, genetic, transcriptomic and genomic perspective, Biological Research. Santiago, 46(3) (2013) DOI: 10.4067/S071697602013000300001

24. E.N. Sedov, Z.A. Sedova, S.A. Streltsina, Breeding for productivity and product quality, in Program and method of the breeding of fruit, berry and nut crops, 48-57 (VNIISPK, Orel, 1995)

25. Yu.A. Smirnov, G.S. Smirnova, R.E. Bogdanov, Plum, in Creation of new varieties and donors of valuable traits based on the identified genes of fruit plants, 53-63 (Michurinsk, 2002)

26. V. Sun, Inheritance and variability on stability of size and size on fertility with offspring from Chinese plum (P. salicina Lindl.), J. Mount. Agr. Balkans, 7(1), 61-69 (2004)

27. Program and method of variety study of fruit, berry and nut crops (VNIISPK, Orel, 1999)

28. Program and method of the breeding of fruit, berry and nut crops (VNIISPK, Orel, 1995)

29. B.A. Dospehov, The method of field experience (Agropromizdat, Moscow, 1985) 